\title{
Die betekenis van Abraham Kuyper (1837-1920) vir Suid-Afrika op kerkhistoriese en kerkregtelike gebied
}

\author{
AD Pont
}

\begin{abstract}
The influence of Abraham Kuyper (1837-1920) on South Africa in the spheres of Church History and Church Polity

A short biography of Kuyper is followed by an attempt to qualify him as a typical theologian of the 19th century, as leader of the Doleantiemovement in the Dutch church and as a man of many parts.

His personal contact with South Africa is traced, as well as his direct and indirect influence in the South African churches. It is interesting to note that the influence of Kuyper's theology in the Gereformeerde Kerke in Suid-Afrika was largely initiated by JD du Toit while his father, SJ du Toit, introduced Kuyper's theology in the Nederduitse Gereformeerde Kerk. Subsequently it was mainly the influence of the VU (Bavinck and Rutgers) which prevailed in the abovementioned churches.
\end{abstract}

\section{INLEIDING}

By die 150-jarige herdenking van die geboorte van Abraham Kuyper, is dit seker vanselfsprekend dat na sy nalatenskap gekyk sal word. Dit staan vas dat Kuyper gedurende sy lewe, deur sy optrede en geskrifte, ' $n$ groot invloed in die Nederlandse en vandaar in die gereformeerde wêreld gehad het. Opvallend is, as sy geskiedenis weer nagegaan word, nie alleen sy groot skriftelike nalatenskap nie, maar ook die wye terrein waarop hy beweeg het (De Bie 1943: 348-406). Terselfdertyd is dit merkwaardig dat byna elke beoordeling van Kuyper en sy werk in die oortreffende trap gestel word, deur sowel mede- as teëstander.

Kuyper begin sy openbare lewe as gedoktoreerde predikant in die Nederlandse Hervormde Kerk as hy in 1862 in die gemeente Beesd

* Referaat gelewer by die Kuyper-Herdenking, 19 Mei 1987 by die Universiteit van die Oranje-Vrystaat, Bloemfontein. 
bevestig word. Agtereenvolgens staan hy dan in Utrecht (1867) en Amsterdam (1870). Sy predikantsamp lê hy in 1874 neer as hy verkies word tot die Nederlandse parlement. In dié werkkring staan hy tot 1877 . In 1897 word hy benoem as teologiese professor aan die Vrije Universiteit van Amsterdam wat op 20 Oktober 1880 geopen word.

In 1894 keer Kuyper terug na die parlement as leier van die Antirewolusionêre Party en van 1901-1905 is hy Eerste minister van 'n koalisieregering. Dit het onder andere beteken dat hy in 1901 sy professoraat aan die Vrije Universiteit moes neerlê.

$\mathrm{Na}$ die val van sy regering keer Kuyper vir die periode 1908-1912 weer terug na die parlement, maar moet in 1912, vanweë toenemende hardhorendheid, dié taak neerlê. Daarna het Kuyper in sy familiekring bly woon, versorg deur sy dogters want sy eggenote het hom reeds in 1899 ontval. Op 8 November 1820 is Kuyper in Amsterdam oorlede en daar begrawe (Rullmann 1928: 1-231).

In die bietjie meer as tagtig jaar wat Kuyper geleef het, het hy op elke lewensterrein waarop hy beweeg het, onmiskenbaar 'n stempel afgedruk en moet hy as een van die groot figure van die 19 de eeu beskou word.

\section{KUYPER, 'N FIGUUR UIT DIE 19DE EEU}

As daar gevra word na 'n sleutel om Kuyper se betekenis te peil, dan moet seker gevra word na die groot doelwit wat Kuyper self vir sy lewe en werk gestel het. Daardie doelwit-omskrywing kan gevind word in die Voorrede van deel I van sy Encyclopaedie der Heilige Godgeleerdheid. Daar verwys hy na

... de sterk sprekende behoefte, om de Gereformeerde Theologie, die als zoodanig reeds sinds het midden der vorige eeuw den slaap der tragen sliep, weer wakker te schudden en in rapport te brengen met het menschelijk bewustzijn, gelijk zich dit aan het einde der 19de eeuw ontwikkeld heeft.

Teen die moderne humanisme, wat vanaf die dae van die Verligting so breed ontwikkel het, teen die 19de eeuse Duitse idealisme wat Europa verower het, wil Kuyper die kerklike, staatkundige en kulturele lewe weer laat bepaal deur sy wysbegeerte van die openbaring. Haitjema tipeer Kuyper se strewe as '... de herkerstening der cultuur in de 
Europees-Amerikaanse beschavingskring' (Haitjema 1964: 229). Dit lyk aanvaarbaar om Kuyper in dié lig te sien en te beoordeel.

Kuyper se oorspronklike aanvaarding van die Idealisme, soos uiteengesit deur sy moderne leermeesters Scholten en Rauwenhoff (Rullmann 1928: 15) word omgestel deur sy drie groot godsdienstige ervarings: in 1860 met sy lees van Yonge se roman, The heir of Radcliffe; in 1866 met sy aanvaarding van die konventikelvroomheid wat bepaal is deur die Nadere Reformatie; en in 1875-1876 wanneer hy die invloed van die Brighton-revivals ervaar.

Sy eerste godsdienstige ervaring van 1860 wat hom tot sondebesef, ootmoedige skuldbelydenis en ' $n$ innige gebedshouding bring (Rullmann 1928: 18-22), word opgevolg deur sy kontak met Pietje Baltus (Rullmann 1928: 29). Dit laat hom vanuit die etiese hoek van die Nadere Reformatie Calvyn lees en daarmee saam die werke van Chantepie de la Sausaye snr, Gunning en die Duitse Vermittlungstheologie (Rullmann 1928: 30-31). Hoewel sy mening oor die Vermittlungstheologie nie gunstig is nie en hy in 1872 die kontak met die Etiese teoloë verbreek (Rullmann 1928: 59), bring sy teologiese vertrekpunt mee dat hy 'n besondere waardering vir die 17de eeuse dogmatikus Maccovius handhaaf (Haitjema 1964: 236). Iets meer blyk ook daarvan dat hy, in antwoord op 'n Groningse prysvrag, 'n dissertasie skrywe waarin hy die kerkbegrip van Calvyn en à Lasco ontleed en met mekaar vergelyk. In dié werk, wat hy in 1862 in enigsins verwerkte vorm as sy doktorale proefskrif aanbied, gee hy 'n duidelike voorkeur aan die kerkbegrip van à Lasco (Kuyper 1862: 187-188), wat die kerk primêr omskryf as 'n societas fraterna Dei liberorum (Kuyper 1862: 178). Later sal Kuyper in sy Encyclopaedie (Kuyper 1909: III, 228) stel dat dit wat die kerk tot kerk maak, naas Woord, sakrament en die ampte, die assosiasie van die gelowiges is. Soos die antropologiese aksent in sy kerkbegrip die klemtoon kry, so word sy teologiese denke oor kerk, volk en staat, sy siening van die kultuurtaak en sy politieke denke, deur dieselfde klemtoon bepaal. Juis daarin is Kuyper nie net'n tipiese 19de-eeuer nie, maar ook as 't ware vasgevang in die 19 de eeu.

\section{KUYPER DIE GROOT LEIER VAN DIE DOLEANSIE}

Dit is as leier van die Doleansie-beweging en as generaal van die gereformeerde denke dat Kuyper 'n permanente plek in die Nederlandse kerkgeskiedenis gekry het. Met groot erns het Kuyper, na sy eerste godsdienstige ervaring in 1860, gesoek na 'n kerk wat soos 'n 
moeder van die jeug af, elke stap van die gelowige sal lei (Rullmann 1928: 21). Daardie kerk kon jy in die Nederlandse kerk van sy dag nié terugvind nie en met groot erns het hy hom beywer vir 'n kerk wat met 'n lewende verantwoordelikheid vas sou staan in die wêreld, wetende dat die kerk geen ander roeping het as om die evangelie van Jesus Christus te verkondig nie.

Om die situasue waarin Kuyper hom bevind het enigermate te kan peil, sal dit miskien goed wees om 'n tweetal tiperings van die kerklike toestand in die tweede helfte van die 19de eeu aan te haal. Haitjema (1936: 260) stel:

De ruim tien jaren, die aan de Doleantie voorafgingen, waren in de oude Hervormde kerk jaren geweest, waarin door middel van allerlei voorstellen tot reglementswijziging steeds hardnekkiger gepoogd werd om de Kerk als Kerk sprakeloos te maken, en in de kerkelijke praktijk de begrenzing op te heffen, die toch door de aanwezigheid eener kerkelijke belijdenis onmiskenbaar schenen te worden voorondersteld. . . . Is het wel wonder, dat in die jaren het non possumus van veler lippen weerklonk, ook wel onder de Christusbelijders, die nu niet bepaald tot de 'Gereformeerde partij' van Dr A Kuyper wilde gerekend worden? Neen, men mag hier niet zeggen dat alles vooropgezette dwarsdrijverij van Kuyper en Rutgers was in het kerkelijke conflict van 1886. Hier was ook de zielekreet, uit veler boezem geperst: wij moeten trouw zijn aan onze Koning Jezus Christus. De Kerk, die het Verbond opzettelijk ontheiligd, zal ondergaan!

Het was inderdaad ergerlijk, dat vele kerkelijke wetgevers hoe langer hoe brutaler probeerden allen open plekken in den mantel der reglementen, waardoorheen noch iets van het echte wezen der Kerk doorschemerte, angstvallig toe te stoppen. Zóó moest de Hervormde Kerk op het vredig samenwonen der meest verschillende richtingen worden ingericht.

Kuyper het tereg iets anders gesoek as die uiterlike kerklike struktuur waarin hy moes leef en werk. Immers, daar het alles op losse skroewe gestaan en elkeen moes maar sy eie heil uitwerk (Kuyper 18-68: 6-28). Dit klink byna onvoorstelbaar as die volgende prentjie van die destydse Hervormde Kerk geteken word (Reitsma en Lindeboom 1949: 492):

De moderne predikanten brachten een geheele omkering niet alleen in hun preekmethode maar ook in de liturgie teweeg. $\mathrm{Zij}$ maakten geen bezwaar om hun prediking te richten tegen alles, 
wat zij verouderd of onhoudbaar achten, en veroorloofden zich de vrijheid belangrijke wijzigingen in de kerkelijke plechtigheden aan te brengen door ander doopformulen uit te spreken, de vragen bij de aanneming tot lidmaat en bij de voorbereiding tot het Avondmaal naar hun opvatting te verbeteren, de meeste liturgische formulieren naar tijdsgelegenheid in een anderen toon om te zetten. Deze nieuwigheden verwekten groote ergernis.

In sy intreepreek te Utrecht in 1867 stel Kuyper baie duidelik dat die gelowige lidmaat van die kerk vastheid en bestendigheid mag verwag in die kerklike reg, die belydenis en die erediens. Die Hervormde kerk het daardie vastigheid verloor. Daarom stel Kuyper met groot oortuiging: 'Of we dus tot kerkherstel of tot stichting eener nieuwe kerk ons moeten opmaken, tot bouwen zijn we in elk geval geroepen ....' (Rasker 1974: 174).

In die pad wat hy dan gaan, kies Kuyper teen die bestaande volkskerk-struktuur wat as geestelike erfgoed in die reglementekerk oorgebly het. Vir die volkskerk-struktuur het Kuyper nie veel waardering gehad nie en gewoonlik het hy daarna verwys as 'de Joodsche zuurdesem van de volkskerk' of 'de oud-Joodsche geest, die Europa nog vergiftigt' (Kuyper sj: 140-141). Teenoor die sinodale hiërargie het hy die outonome plaaslike gemeente gestel en só 'n kerkbegrip opgebou uit die bewuste belydenis van die enkeling. Daarmee het hy die genadeverbond, as die basis van die kerk soos dit by Calvyn gevind word, verwerp (Avis 1981: 8). Dat Kuyper die vrye-kerkgedagte na vore bring in sy stryd teen die sinodale hiërargie, is verstaanbaar want dit is 'n vraag of dit in die versekulariseerde Europa nog moontlik was om weer na die teokratiese ideaal van die reformatore terug te keer. Kuyper was van oordeel dat dit, vanweë die gang van die tyd, nie meer moontlik was nie. Dat hy verder die leer van die uitverkiesing die basis van die kerk maak, hang saam met sy enigsins uitsonderlike leer van die weergeboorte en wat daarop volg (Kuyper sj: IV, 70).

Daarby het Kuyper teen die sinodale hiërargie en die 'driewerf van van den Heere Heere gevloekte organisatie', die argument in die veld gestoot dat die sinode geen belangstelling vertoon om die belydenis van die kerk te handhaaf nie (Kuyper 1868: $112 \mathrm{vg}$ ). Daarom het Kuyper die sinodale hiërargie sy bestaansreg ontsê en dit beklemtoon dat die plaaslike gemeente altyd en in die eerste plek die kerk is (Kuyper 1874: 26). Vir dié opvatting beroep Kuyper hom enersyds op die demokratiese aard van die Calvinisme (Kuyper 1873: 79) en andersyds op die 
voorbeeld van die Independente uit die Engels-puriteinse geskiedenis (Kuyper 1874: 32). Soos Kuyper dit sien, is dit die taak van die selfstandige plaaslike gemeente om na vrye keuse hulleself te verenig in 'n konfederatiewe verband. Só gesien kan die algemene kerk niks anders wees nie as 'n verbond van selfstandige gemeentes. Reeds in 1873 (Kuyper 1873: 63-105) het Kuyper aangetoon hoe die kerk moet wees waarna hy strewe: 'Gereformeerd en democratisch, vrij en zelfstandig, en zoo in de leerdienst als eeredienst en liefdesdienst volledig georganiseerd ....'

Dié vrye kerkgedagte is deur Kuyper as ' $n$ vanselfsprekenheid in die gereformeerde kerkreg ingedra en hy vind daarvoor nie net aansluiting by Gijsbertus Voetius, die 17de eeuse canonicus nie (Polit Eccl: I, 61-65) maar ook by à Lasco en vandaar by die $17 \mathrm{de}$ eeuse Puriteinse independente. Hieruit blyk weer dat Kuyper steeds die antropologiese kant van die kerk as 'n gemeenskap van gelowige enkelinge beklemtoon.

In sy stryd een die sinodale hiërargie vorm Kuyper se Tractaat van de Reformatie der Kerken van 1883, 'n uiters belangrike dokument omdat daarin die program vir die doleansie uiteengesit word. Hier stel Kuyper dat die plaaslike gemeente bestaan '. . . omdat het leven Christi in haar openbaar wordt' (Kuyper 1884: 147). Daarmee beklemtoon hy 'n waarheid wat in die 19de eeu byna vergete was. Aan die ander kant is dit so dat Kuyper met sy beklemtoning van die outonomie van die plaaslike gemeente weer te ver gaan as hy stel dat die ou volkskerk opgebreek moet word in 'n veelheid van kerke (Van Deelen 1936: 245). Opvallend is sy stelling dat die pluriformiteit 'een noodzakelijke werking van de door God gestelde levensordinantie' is (Kuyper sj: III, 291), en dat die strewe om kerke met dieselfde belydenis weer sigbaar een te maak 'niet anders dan met het medelijden van den weemoed' beskou moet word omdat daardie strewe van meet af 'met volstrekte onvruchtbaarheid geslagen zijn' (Kuyper sj: III, 235). Hier moet egter bygesê word dat Kuyper met sy aanvaarding van die vrye kerkgedagte en met die ontwikkeling van sy pluriformiteitsleer, nie 'n sinlose versplintering in gedagte het nie. Juis met sy stellings wil Kuyper veel eerder die pluriforme waarheid van God in al sy krag ongerep vir die hele volk, meer nog, vir die Europees-Amerikaanse kultuurkring bewaar.

Kuyper se doleansie dra uiteindelik die vrug dat die dolerende kerke in ' $n$ konfederatiewe verband met die belydenis as grondslag, saamkom in ' $n$ sinode te Utrecht in 1888 waar die amptelike naam: Nederduitsch Gereformeerde Kerken aanvaar is. In 1892, toe die kerke van die 
afskeiding en die doleansie mekaar gevind het, word die naam: de Gereformeerde Kerken in Nederland. Met die doleansie het ongeveer 200000 lidmate en ampsdraers uit die Hervormde Kerk getree. Die vraag is of die doleansie toe in sy doel geslaag het want die verwagting was dat al die plaaslike gemeentes, met behoud van hulle kerklike goedere, uit die sinodaal-georganiseerde Hervormde Kerk moes tree. Dit het egter nie gebeur nie, terwyl die kerkverlaters ook hulle aansprake op die kerklike goedere moes prysgee. Uiteindelik het dit egter nie om getalle of goedere gegaan nie, maar om die behoud en vestiging van ' $\mathrm{n}$ bepaalde kerklike teologie en tradisie.

\section{KUYPER DIE VEELSYDIGE}

Kuyper se enorme kragsontplooiing binne die ruimte van die kerk was die komplement van sy arbeid op die breëre terrein van die wetenskap, die kultuur en die staatkunde. Waarskynlik is die grootste monument van sy organisatoriese en skeppende arbeid die oprigting van die Vrije Universiteit te Amsterdam in 1880.

Reeds in 1870 , betreklik vroeg in sy loopbaan, het Kuyper die noodsaaklikheid van tersiêre onderwys na die eis van die Woord van God bepleit, dit as noodsaaklike komplement vir sy bemoeienis op die vlak van die primêre en sekondêre onderwys.

Die aanleiding tot die stigting van die Vrije Universiteit was ongetwyfeld die aanvaarding in 1876 van die Wet op 't Hooger Onderwijs. Daarvolgens sou die teologiese fakulteit aan die staats-universiteite omvorm word tot fakulteite van godsdienswetenskap waar vir die eiesoortigheid van die Christelike teologie nie meer plek sou wees nie. Om dié oorgang minder pynlik te maak, het die owerheid aan die kerk die moontlikheid gegee om staatsgesubsidieerde kerklike leerstoele aan die universiteite in te stel sodat die opleiding van predikante daar voortgang kon hê. Die sinode het daarvan gebruik gemaak en feitlik al dié leerstoele gevul met manne wat die Groningerrigting in die teologie aangehang het. Dit het beteken dat vir die Bybelse en reformatoriese teologie daar eintlik geen plek meer aan die Nederlandse staatsuniversiteite was nie.

Met ' $n$ geweldige kraginspanning het Kuyper die stigting en finansiering van die Vrije Universiteit moontlik gemaak. Op 20 Oktober 1880 het Kuyper met 'n magistrale openingsrede getitel Souvereiniteit in eigen kring die nuwe Universiteit geopen. Met die oprigting van die Universiteit en deur sy opvolgende werk het Kuyper die fondamente gelê van 
wat Veenhof (1939: 5) noem: '. . . een van den Gereformeerden, Schriftuurlijke geest doortrokken wetenschap ....' Kuyper het baie goed besef dat hy hier maar met die eerste begin besig was, maar hier word ook waar wat Haitjema (1936: 259) gestel het:

Wij hebben in Kuyper niet te doen met een bekrompen exclusivist, doch veeleer met een figuur vol martiaal idealisme en cultuuruitzichten van wereldwijde visie.

Daarom het Kuyper met nadruk gevra of die logiese, ontologiese, kosmologiese en antropologiese beginsels wat in elke onderafdeling van die menslike wetenskap heerskappy voer, ooreenstem met die beginsels van die Calvinisme en of dit daarteen ingaan (Kuyper 1898: 177-178). Vir Kuyper was die Vrije Universiteit die beginpunt van die bestryding van die Duits-idealistiese mensopvatting en lewensbeskouing wat destyds die Europese kultuur- en dinkwêreld beheers het. Tot aan die einde van sy aktiewe professoraat in 1901 het Kuyper hom met hierdie taak besig gehou en daarmee die weg voorberei vir die werk wat later deur Vollenhoven en Dooyeweerd aangepak sou word. Dit lê natuurlik in die lyn van Kuyper se denke dat die herkersteningstaak nie primêr aan die kerk toevertrou sal word nie, maar in die hande sal wees van gelowiges wat hulle inspirasie uit die kerk en sy boodskap geput het. Hoewel oor die grondslae en inhoud van sy filosofiese werk verskil kan word, bly dit waar dat Kuyper een van die min teoloë van die 19de eeu was wat met insig, durf en daad ' $n$ keerwal teen die sekularisasieproses opgewerp het.

Vir hierdie aggressiewe aksie het Kuyper sy opvattings oor die partikuliere of besondere genade aan die een kant en die algemene genade aan die ander kant, ontwikkel. Daarmee handhaaf hy sy opvatting van die antitese tussen kerk en wêreld en die stelreël dat die kerk in die wêreld net kerklik kan funksioneer. Op hierdie punt gaan Kuyper inderdaad ' $n$ ander weg as Calvyn (BJ Engelbrecht sj: 19). Waarskynlik lê hieraan ten grondslag Kuyper se verwerping van die verbondsteologie soos dit by die reformatore ontstaan het en veral deur die teoloë van die 17 de eeu verder ontwikkel is. Juis so wou Kuyper die gereformeerde teologie weer wakker skud en dit relevant maak vir die mens van die 19 de eeu.

Kuyper se akademies-wetenskaplike arbeid van die jare 1879-1901 kon populêre steun vind en in wyer kringe weerklink omdat sy arbeid op die politieke terrein reeds vir hom 'n klankbord gebou het. Kuyper se bemoeienis met die politiek begin in Oktober 1869 wanneer hy begin 
om politieke artikels vir die weekblad, De Heraut, een Nederlandsche Stem voor Israëls Koning, het Hoofd der Gemeente, onder redaksie van dr C Schwartz, te skrywe. Vanaf 1871 word Kuyper hoofredakteur en word die blad die eiendom van 'n vereniging wat Kuyper daarvoor opgerig het. Die blad kry nou die naam: De Heraut voor Vrije Kerk en Vrije School in het Vrije Nederland. Dié blad het so voortbestaan tot 1872. Kuyper het egter besluit om eerder 'n politieke dagblad op te rig en vanweë sy bemoeienis met die saak kan op 1 April 1872 die eerste uitgawe van De Standaard, onder Kuyper se redaksie verskyn. Dié blad waaraan Kuyper vir 45 jaar sy kragte en aansienlike talente wy, word die mondstuk van die Anti-rewolusionêre Party wat aanvanklik onder die leiding van Groen van Prinsterer gestaan het. De Standaard het vanweë Kuyper se besondere joernalistieke talent in die politieke lewe van Nederland groot invloed uitgeoefen en dit was terselfdertyd die middel by uitstek waardeur Kuyper sy gedagtes oorgedra het. In 1887 het De Heraut weer sy verskyning gemaak, nou ter vervanging van die Zondagsblad wat as 'n bylaag van De Standaard verskyn het. In De Heraut van de Gereformeerde Kerken in Nederland het Kuyper tot in November 1920 sy teologiese, dogmatiese en kerklike opvattings ontwikkel en verbrei. Deur sy joernalistieke bekwaamhede het Kuyper daarin geslaag om sy gedagtes en opvattings in 'n wye kring te laat posvat.

In die politieke lewe self het Kuyper die politieke program van die Anti-rewolusionêre party in besonderhede uitgewerk in sy breedopgesette publikasie, Ons Program, van 1878. Miskien is dit tog interessant om één van Kuyper se stellings in hierdie verband aan te haal. So stel hy (Kuyper 1880: 26):

Maar de hoofdzaak, waarop we staan, en waarvan we niet kunnen aflaten, is deze:

1. Nederland worde ook als staat niet vijandig tegenover den levenden God gesteld;

2. Nederland ruile de puriteinsche regeeringsbeginselen niet weer uit voor de Roomsche;

3. Nederland geve zijn vaderlandsche instellingen niet voor het namaaksel van den vreemden prijs.

As slegs na Kuyper se arbeid op die joernalistieke en politieke vlak gekyk word, is dit opvallend dat hy dit te midde van sy kerklike en teologiese arbeid kon volgehou het. Danksy sy geweldige werkkrag, sy byna ensiklopediese kennis en sy vermoë om sy gedagtes só uit te druk dat sy volgelinge hom kon verstaan, het hy daarin geslaag om ook op 
hierdie vlak besondere hoogtes te bereik. Meer as enige ander teoloog van sy tyd het hy daarin geslaag om vanuit die vertrekpunt van die reformatoriese teologie, 'n keerwal op te werp teen die heersende humanisties-sekulêre opvattings en lewenshouding van sy tyd.

\section{KUYPER EN SUID-AFRIKA}

Dit is nie so 'n eenvoudige saak om presies te bepaal wat Kuyper se invloed op ons kerke, teologie en samelewing was nie. Want eers op grond daarvan kan iets oor sy betekenis gesê word. Miskien kan dié saak van twee kante besien word.

\subsection{Kuyper se persoonlike kontak met Suid-Afrika}

Dit is duidelik dat Kuyper, te midde van sy geweldig werklas en sy bemoeienis met soveel sake in sy eie vaderland, nie te veel tyd tot sy beskikking kon gehad het om ook nog belangstelling vir Suid-Afrika en sy probleme te hê nie. Tog val dit op dat in 'n tyd toe in Nederland die verbondenheid met Suid-Afrika en met name met die Boererepublieke sterk gevoel is, Kuyper ook bewustelik kennis geneem het van die situasie in Suid-Afrika en die probleme wat daar bestaan het. So is dit tog interessant om vas te stel dat van Transvaalse kant verskillende male met Kuyper kontak gemaak is om van hom raad in te win of hulp te vra (Kruger 1963: II, 14 en 102). In 1883 het Kuyper selfs na Londen gegaan om 'n afvaardiging van die Zuid-Afrikaansche Republiek wat toe in Engeland was, van advies te bedien (Kruger 1963: II, 40). Daarom is dit miskien te verstane dat hy in 1884, met die verwelkoming in Nederland van 'n Zuid-Afrikaansche Republiek-deputasie wat in Engeland was, gestel het (Rullmann 1928: 121):

Wie weet hoe hoog die spanning der gemoederen nog klimmen, tot welke toestanden het in ons midden nog komen kan? ...

Maar ook dan, geen nood! Immers, waar men ons hier dan niet meer als vrije mannen duldde, kont gij ons een toevluchtsoord en een plaats der ruste aanbieden. Maakt men het hier ons Christenvolk ondraaglijk, dan gaat de kern van dat Christenvolk de zee over naar Transvaal.

Waarskynlik vanuit daardie gevoel van verbondenheid met die Afrikaner het Kuyper in 1900 sy bekende De crisis in Zuid-Afrika geskryf wat 
ook in Engels vertaal en in Engeland versprei is. Hierdie werk van Kuyper getuig nie alleen van heelwat navorsing wat hy moes doen nie, maar ook van 'n merkwaardige insig in die karakter, opvatting en uitkyk van die republikeinse Afrikaner. Terselfdertyd blyk dit dat Kuyper 'n goeie begrip het van die egoïstiese element in die Engelse imperialisme en die gebrek aan ' $n$ morele basis vir hulle optrede in Suid-Afrika. Opvallend is sy byna profetiese uitspraak (Kuyper 1900: 62):

Om de Boeren met ruw geweld te kunnen overwinnen zal Engeland hen moeten uitroeien, hen wegvagen uit de rij der natiën. Dan, ja dan, zou Zuid-Afrika alleen voor de Engelschen zijn . . . en de negers. Maar daar de bloote gedachte aan zulk een gruweldaad den Engelschen doet ontstellen en hun geen oogenblik in den geest komt, mogen zij wel weten dat het voortgaan op den weg des gewelds ontwijfelbaar zou zijn: het begin van het eind voor Engelands macht als groote mogendheid.

Dit het vir Kuyper nie net by die publikasie van hierdie brosjure gebly nie. As Nederlandse Eerste Minister het hy 'n reis na Londen onderneem om daar ' $n$ poging aan te wend om Engeland te oortuig om die oorlog te staak. Terselfdertyd het hy die Nederlandse regering so ver gekry om 'n diplomatieke Nota aan die Engelse regering in verband met die oorlog te stuur. Hoewel dié bemoeienisse geen sigbare vrugte afgewerp het nie, is dit wel van belang om dit te vermeld.

Oor die algemeen egter kan gestel word dat Suid-Afrika en die Afrikaner nie 'n bepalende plek in Kuyper se denke en dade ingeneem het nie, hoewel hy altyd simpatiek teenoor die Afrikaner gestaan het en na die Engelse Oorlog met begrip teenoor die banneling-president Paul Kruger, opgetree het.

Wat die akademiese vlak betref, is dit so dat net een Afrikaner aan die Vrije Universiteit gestudeer het in die jare toe Kuyper daar teologiese professor was. Selfs na die stigting van die Vrije Universiteit in 1880, het die meeste Afrikaners wat in Nederland studeer het, hulle nog na die staatsuniversiteite begewe (Serfontein et al 1954: 77-78). Die eerste Afrikaner wat by die Vrije Universiteit studeer het, was die teoloog JD du Toit wat in 1900 in Nederland aangekom het en in 1903 daar gepromoveer het (Pont 1935: 65). Dit was nie so vreemd dat JD du Toit na die Vrije Universiteit gegaan het nie want sy vader, ds SJ du Toit, wat self die stigting van die Vrije Universiteit in Amsterdam bygewoon het, was 'n groot bewonderaar van Kuyper. SJ du Toit het reeds vanaf 
die sewentigerjare moeite gedoen om Kuyper en sy denke in die Nederduits Gereformeerde Kerk bekend te stel.

Hoewel JD du Toit nie veel van Kuyper as hoogleraar beleef het nie, omdat Kuyper in 1901 sy aktiewe professoraat neergelê het, het hy die res van sy lewe 'n besondere waardering vir Kuyper behou. Grootliks vanweë JD du Toit se invloed het Kuyper se teologiese denke in die Gereformeerde Kerke in Suid-Afrika aanvaarding gevind. Tog bly dit waar dat direkte akademiese kontak en beïnloeding deur Kuyper, wat Suid-Afrika betref, beperk was.

\subsection{Kuyper se indirekte invloed op Suid-Afrika}

Om Kuyper se indirekte invloed op Suid-Afrika, sy kerke, skool en openbare lewe te meet, is waarskynlik 'n onbegonne taak. Tog kan dié invloed enigermate gepeil word as gelet word op die Afrikaners wat in Nederland aan die Vrije Universiteit studeer het.

Aanvanklik was dit hoofsaaklik jong manne uit die Gereformeerde Kerke in Suid-Afrika wat vir studie en opleiding na die Vrije Universiteit gegaan het. Tog moet hier gestel word dat die teologiese opleiding te Kampen, waar die opleiding gevestig was van die Christelijk Afgescheiden Gemeenten tot 1892 en daarna as 'n tweede opleidingsentrum van die Gereformeerde Kerken in Nederland gedien het, steeds manne uit die Gereformeerde Kerke alhier getrek het. Algaande het die Vrije Universiteit egter 'n oorheersende aantrekkingskrag ook vir studente uit hierdie kerke ontwikkel.

Dit is opvallend dat in die jare na die Engelse Oorlog geleidelik al meer manne uit die Nederduits Gereformeerde Kerk vir die voltooiing van hulle teologiese studie na die Vrije Universiteit gaan. Tot 1900 het die meeste Afrikaners hulle skrede na die staats-universiteite en veral na Utrecht gewend. As 'n rede hiervoor aangedui kan word, dan hang dit waarskynlik saam met die teologiese gerigtheid van die fakulteite aan die staatsuniversiteite èn die feit dat die Nederduitse Gereformeerde Kerk self deur die Réveilbeweging beïnvloed is en daardeur ook sterk antiteties teenoor die heersende teologiese klimaat in die Nederlandse Hervormde Kerk gestaan het (Van Rooyen 1934: 128-158).

Van die bekendste manne uit die Nederduits Gereformeerde Kerk wat in die vroeë jare na die Vrije Universiteit gaan, was seker BB Keet wat in 1913 en EE van Rooyen wat in 1914 aan die Vrije Universiteit gepromoveer het. Die feit dat sowel Keet as Van Rooyen professorate by die Stellenbosse Kweekskool beklee het, het meegebring dat die in- 
vloed van die Vrije Universiteit en sy teologie verder in die Nederduits Gereformeerde Kerk uitgekring het. Dit sou egter te ver gaan om hier met sekerheid te bepaal in hoeverre Keet en Van Rooyen binne die bane van die Vrije Universiteit se teologie gebly het en hoe hulle die teologiese ontwikkeling in die Nederduits Gereformeerde Kerk beïnvloed het.

Na Keet en Van Rooyen het dit so gebeur dat die meerderheid teoloë van die Nederduits Gereformeerde Kerk wat hulle studies in die buiteland gaan voortsit het, dit aan die Vrije Universiteit gedoen het. Dit is in hierdie verband nogal opvallend dat in daardie vroeë jare 'n betreklike groot getal kwekelinge van Stellenbosch vir' $n$ jaar of meer aan die Vrije Universiteit studeer het sonder om hulle studie met 'n promosie af te rond. Hierdie manne het by hulle terugkeer in SuidAfrika seker bygedra om die invloedsfeer van die Vrije Universiteit se teologie in die Nederduits Gereformeerde Kerk te verbreed. As daarby in ag geneem word dat die 'tweede generasie' van dosente aan die Stellenbosse Kweekskool byna almal aan die Vrije Universiteit gepromoveer het, kan die invloed van die Vrije Universiteit op die teologiese inhoud van die Nederduits Gereformeerde Kerk as aansienlik getipeer word.

In hoeverre dit alles Kuyper se teologie en sienswyses na Suid-Afrika oorgedra het, is moeiliker om te bepaal, juis omdat Kuyper self so kort as teologiese hoogleraar aan die Vrije Universiteit verbind was. Daarby moet seker in ag geneem word dat prof Herman Bavinck, wat vanaf 1902 hoogleraar aan die Vrije Universiteit was, die dogmatikus by uitstek van die Gereformeerde Kerke geword het. In verskillende opsigte het Bavinck se werk en invloed Kuyper se opvattings op die vlak van die dogmatiek en die ekklesiologie verbeter of gewysig.

Dieselfde kan gesê word van Kuyper se invloed op die kerkregtelike vlak. Want dit is duidelik dat prof FL Rutgers, die groot canonicus van die Vrije Universiteit, heelparty van Kuyper se uitsprake wat in die hitte van die stryd gemaak is, getemper en gewysig het. Juis daarom is dit nié so maklik om Kuyper se eie, direkte invloed op Suid-Afrika en die teologiese ontwikkeling alhier te peil nie.

\section{KUYPER SE BETEKENIS}

As nou, ten slotte, gevra word na Kuyper se betekenis ook vir ons, dan is dit uit die voorafgaande duidelik dat Kuyper se werk wel betekenis gehad het en wel in ' $n$ direkte en ' $n$ indirekte sin. Selfs waar momente 
uit Kuyper se teologie nié aanvaar is nie, het dit tog dié betekenis gehad dat hy sy teenstander gedwing het om op deugdelike gronde van hom te verskil.

Seker die eerste betekenis wat Kuyper gehad het, was die feit dat hy teen die skynbaar onstuitbare voortgang van die Duitse idealisme en die teologieë wat daarmee verwant was, opgestaan het en wal gegooi het. Dit alleen was al van wesenlike belang omdat die teologieë van daardie tyd, gedra deur 'n optimistiese voortgangsgeloof, gemeen het dat alleen die nuwe en die hedendaagse belangrik geag moet word. Die verlede, die teologiese en kulturele erfgoed, is as verouderd en daarom as uitgedien en waardeloos van die tafel afgevee. Daardie verbasende hooghartigheid is deur Kuyper met mening bestry. Juis daarom het Kuyper so sterk die aandag gevestig op die geestelike erfgoed van die kerk. Sy kerkhistoriese studies oor à Lasco, Junius, die begindae van die Nederlandse vlugtelinggemeente in Londen en sy herpublikasie van die Nederlandse vertaling van Calvyn se Institusie toon aan hoe Kuyper daarin geslaag het om die geskiedenis, wat nooit heeltemal voltooide verlede is nie, weer in sy eie tyd te laat spreek.

Dit is belangrik om daarop te let dat Kuyper in sy stryd teen die gees van die eeu, sy vertrekpunt en inspirasie by Johannes Calvyn vind. En al is dit so dat Kuyper vanuit die hoek van die Nadere Reformasie Calvyn lees en verstaan, bly die feit steeds staan dat hy juis dáár die kerk leer ken as 'n gemeenskap van gelowiges en dat die grense en inhoud van die gemeenskap se geloof deur die belydenis bepaal word. $\mathrm{Al}$ is dit so dat Kuyper se verdere tipering van die kerk as ' $n$ moeder vir die gelowiges ' $n$ effens ander aksent dra as wat die begrip by Calvyn self het, bly ook die ander feit steeds staan dat Kuyper weer die nadruk lê op die kerk, as die liggaam van gelowiges met Christus as die enige Hoof. Daarmee kom Kuyper direk te staan teenoor die kerkbegrip soos dit na vore gekom het in die Algemeen Reglement van 1816 en die daaropvolgende reglemente.

Kuyper se aanval op die eienaardige 19de eeuse kerklike struktuur het hy ondersteun met argumente uit die 16de en 17de eeuse reformatoriese kerklike reg. Dit het vanselfsprekend aan die studie van die kerkreg en die kerkbegrip 'n nuwe impetus gegee. Terselfdertyd het hy daardeur ook sy teenstanders gedwing om hulle posisie grondig te bepaal. Juis omdat Kuyper se stryd 'n stryd om die kerk was, het sowel die locus de ecclesia as die kerklike reg 'n prominente posisie in sy teologiese arbeid gekry. Dit het vir ons die merkwaardige betekenis dat geen kerkregtelike studie gedurende hierdie eeu in ons Afrikaanse 
kerke gepubliseer is wat nie op een of ander manier deur Kuyper se opvattings beïnvloed is nie. Hoewel Kuyper se uiteensettings oor die outonomie van die plaaslike gemeente en sy nogal vergaande pluriformiteitsleer omstrede genoem kan word, is dit tog ook weer so dat in die Nederduits Gereformeerde Kerk en in die Nederduitsch Hervormde Kerk, waar die struktuur wat die Algemeen Reglement gebou het, 'n sekere navolging gevind het, 'n sinodale hiërargie soos die Nederlandse nooit werklikheid geword het nie.

As só na Kuyper se betekenis gevra word, word dit duidelik dat Kuyper inderdaad daarin geslaag het om '. . . de Gereformeerde Theologie ... weer wakker te schudden en in rapport te brengen met het menschelijk bewustzijn, gelijk zich dit aan het einde der 19de eeuw ontwikkeld heeft'. So effektief het hy daarin geslaag dat wanneer sy geskrifte in ons dae bestudeer word, dit soms opvallend is dat hy polemiseer teen opvattings wat niemand vandag meer aanvaar nie. Hoewel Kuyper op sy eie manier en vanuit sy agtergrond die gereformeerde teologie van die $16 \mathrm{de}$ eeu in die 19 de eeu herinterpreteer en vir sy tydgenote toeganklik maak, is dit tog so dat sy werk ook óns kerklike en teologiese lewe beïnloed het. Daarvoor kan talle bewyse uit ons kerklike en akademiese wêreld aangevoer word. Dit kan sonder teenspraak gestel word dat daar nie nóg 'n 19de eeuse Nederlandse teoloog was wie se werk so ' $n$ weerklank in die lewe en werk van al drie Afrikaanse kerke gevind het nie. Dit sal die saak seker te ver voer om dié stelling in besonderhede uit te werk, maar dit staan tog vas dat Kuyper se werk nie één van die Afrikaanse kerke onberoer gelaat het nie.

Samevattend kan gestel word dat Kuyper in die 19de eeu in Nederland as teoloog en as filosoof, as kultuurman en politikus 'n enorme bydrae gelewer het om die optimistiese, humanistiese filosofie en teologie van sy tyd te sluit. Terselfdertyd het sy aansluiting by die teologie van Calvyn en sy eie, verdere ontwikkeling daarvan ook vir die Afrikaner se teologiese denke en sy kerklike en wetenskaplike arbeid, rigting aangedui en stimulerend gewerk.

\section{Literatuurverwysings}

AVIS, PDL 1981. The church in the theology of the reformers. London: Marshall, Morgan and Scott.

DE BIE, JP (red) 1943. Biographisch Woordenboek van Protestantschen Godgeleerden in

Nederland. 's-Gravenhage: Martinus Nijhoff.

ENGELBRECHT, BJ sj. Calvin and the corpus christianum. HTS, Jrg 35, 11-21. 
ENGELBRECHT, SP 1946. Dr A Kuyper en John Milton. HTS, Jrg 3, 46-53.

HAITJEMA, ThL 1936. De doleantie en ons kerkelijk vraagstuk. Onder Eigen Vaandel. Jrg 11, $256-268$.

HAITJEMA, ThL 1964. De nieuwere geschiedenis van Neerlands Kerk der Hervorming. 's-Gravenhage: Boekencentrum NV.

KRUGER, DW 1963. Paul Kruger. Deel II. Johannesburg: Afrikaanse Pers Bpk.

KUYPER, A 1862. Disquisitio historico-theologica, exhibens J Calvini et J à Lasco de ecclesia sententiarum inter se compositionem. 's-Gravenhage: Martinus Nijhoff.

KUYPER, A 1868. Kerkvisitatie te Utrecht in 1868. Utrecht: JH van Peursen.

KUYPER, A 1873. Confidentie. Schrijen aan den Weled Heer JH van der Linde.

KUYPER, A 1874. Het Calvinisme oorsprong en waarborg onzer constitutioneele vrijheden. Amsterdam: Van der Land.

KUYPER, A. 1880. Ons program. Amsterdam-Pretoria: Höveker en Wormser.

KUYPER, A 1884. Traktaat van de reformatie der kerken. Amsterdam: Höveker en Zoon.

KUYPER, A 1900. De crisis in Zuid-Afrika, vertaald door CK Elout uit Revue des deux Mondes. Amsterdam - Pretoria; Höveker en Wormser.

KUYPER, A 1898a. Het calvinisme. Kampen: Kok.

KUYPER, A 1898b. Varia Americana. Amsterdam-Pretoria: Höveker en Wormser.

KUYPER, A 1909. Encyclopaedie der heilige godgeleerdheid. III. Kampen Kok.

KUYPER, A sj. Dictaten dogmatiek van dr A Kuyper. Locus de salute, ecclesia, sacramentis. Kampen: Kok.

KUYPER, A sj. De gemeene gratie. Kampen: Kok.

KUYPER, A 1909. De leer der verbonden. Kampen: Kok.

PONT, JW 1935. Het studiefonds voor Zuid-Afrikaansche studenten 1835-1935. Overzicht van zijn geschiedenis. Amsterdam: De Bussy.

RASKER, AJ 1974. De Nederlandsche Hervormde Kerk vanaf 1795. Kampen: Kok.

REITSMA, J en LINDEBOOM, J 1949. Geschiedenis van de hervorming en de Hervormde Kerk der Nederlanden. 's-Gravenhage: Martinus Nijhoff.

RULLMANN, JC 1928. Abraham Kuyper. Een Levensschets. Kampen: Kok.

SERFONTEIN, WJB, HUGO, AM EN PONT, AD 1954. Suid-Afrikaners in Utrecht 17621954. Utrecht: Kemink en Zoon NV.

VAN DEELEN, HJC 1936. De theologische agtergrond van de doleantie. Onder Eigen Vaandel. Jrg 11. 235-255.

VAN ROOYEN, EE 1934. Die teologiese kweekskool en die handhawing van die gereformeerde leer in Gedenkboek van die Teologiese Seminarie. Stellenbosch: Pro Ecclesia.

VAN RULER, AA sj. Kuypers idee eener christelijke cultuur. Nijkerk: GF Callenbach NV. VEENHOF, C 1939. In Kuyper's lijn. Goes: Oosterbaan en Le Cointre NV. 